UDC 616.99: 578.426

DOI: $10.21668 /$ health.risk/2019.1.07.eng

\title{
MORBIDITY WITH TICK-BORNE VIRAL ENCEPHALITIS IN SOME REGIONS IN URALSKIY FEDERAL DISTRICT WITH PREDICTIVE ESTIMATE OF SHORT-TERM EPIDEMIOLOGIC SITUATION
}

\author{
V.A. Mishchenko ${ }^{1,2}$, O.V. Ladygin ${ }^{1}$, I.P. Bykov ${ }^{1}$, J.A. Zakharova ${ }^{1}$, \\ A.G. Sergeev ${ }^{1,3}$, I.A. Kshnyasev ${ }^{2}$ \\ ${ }^{1}$ Rospotrebnadzor's Yekaterinburg Research Institute of Viral Infections, 23 Letnyaya Str., Yekaterinburg, 620030, \\ Russian Federation \\ ${ }^{2}$ Institute of Plant and Animal Ecology of the Urals Department of Russian Academy of Science, 2028 Marta Str., \\ URAN, Yekaterinburg, 620144, Russian Federation \\ ${ }^{3}$ Ural State Medical University of the RF Public healthcare Ministry, 3 Repina Str., 630028, Yekaterinburg, \\ Russian Federation
}

Extrapolation prediction of epidemic situation as per tick-borne viral encephalitis (TVE) on endemic territories that is based on analyzing time rows of morbidity is a promising approach to be applied in predictive medical-ecological and epidemiologic research.

The authors examined long-term dynamics showing both number of people who suffered from tick bites and morbidity with tick-borne viral encephalitis (TVE) in 4 regions in the Ural Federal District over 2007-2017.

We applied a sum of harmonic functions as a mathematic model; parameters of the functions were detected with Levenberg-Marquardt procedure for non-linear estimates. The technique is flexible and it allows both to apply parameters of harmonic fluctuation that are common for all 4 regions and to estimate parameters that differ in various regions and are of special interest (average long-term values and other fluctuation parameters). One of the research goals was to estimate dynamics in number of people who suffered from tick bites and morbidity with TVE in the Ural Federal District regions over the examined period and to predict epidemiologic situation for the coming years. To do that, we built several harmonic regression models with different number of estimated parameters. To compare and rank the models, we applied Akaike consistent information criterion that determines optimality as a compromise between a model accuracy and complexity.

Our analysis of morbidity with TVE over 2007-2017 in Sverdlovsk, Chelyabinsk, Tyumen, and Kurgan region allowed us to quantify discrepancies in average long-term parameters between these Ural Federal District regions. The highest average long-term morbidity was fixed in Kurgan region; the lowest one, in Sverdlovsk and Chelyabinsk region. But a number of people who suffered from tick bites was higher in Sverdlovsk, Chelyabinsk, and Tyumen region than in Kurgan region over the same period. We showed that long-term fluctuations in ticks activity in the Ural Federal District can be considered in-phase and it can possibly mean there is regional synchronization. We detected quasi-periods of cycles both for number of people bitten by ticks and morbidity with TVE and built a short-term prediction for epidemic situation as per TVE in the region on the basis of the proposed harmonic model for a period up to 2022; a probable TVE morbidity peak can be reached in 2020-2021.

Key words: tick-borne viral encephalitis, morbidity, number of victims, modeling, prediction, selection of models, cyclic fluctuations, parameters.

(c) Mishchenko V.A., Ladygin O.V., Bykov I.P., Zakharova J.A., Sergeev A.G., Kshnyasev I.A., 2019

Vladimir A. Mishchenko - Researcher at the Laboratory for transmissive infections and tick-borne encephalitis, Research Engineer at the laboratory of evolutionary ecology (e-mail: innamoramento23@yandex.ru; tel.: +7 (343) 261-99-47; ORCID: https://orcid.org/0000-0003-4280-283X).

Oleg V. Ladygin - Leading Researcher, Head of the laboratory of transmissive infections and tick-borne encephalitis (e-mail: alibabey@mail.ru; tel.: +7 (343) 261-99-47).

Ivan P. Bykov - Candidate of Medicine, Senior Researcher at the laboratory of transmissive infections and tick-borne encephalitis (e-mail: i.p.bykov@mail.ru; tel.: +7 (343) 261-99-47; ORCID: https://orcid.org/0000-0002-5157-646X).

Julia A. Zakharova - Holder of the postdoctoral degree in medicine, Deputy Director for Science, Head of the department for epidemiology of viral infections, Chief Researcher (e-mail: z.y.alexandrovna@mail.ru; tel.: +7 (343) 261-99-47; ORCID: https://orcid.org/0000-0003-3416-0902).

Alexandr G. Sergeev - Holder of the postdoctoral degree in medicine, Professor, Head of the Microbiology, Virology and Immunology Chair, Head of the Department of Indication and Diagnosis of Viral Infections, Chief Researcher (e-mail: aldr131250@yandex.ru; tel.: +7 (343) 214-86-95).

Ivan A. Kshnyasev - Candidate of Science (Biology), Senior Researcher at the laboratory of population ecology and modeling (e-mail: kia@ipae.uran.ru; tel.: +7 (343) 210-38-58). 
Since tick-borne viral encephalitis (TVE) was discovered in 1937 and up to now epidemiology of the disease has changed greatly; these changes were primarily caused by occurrence of anthropurgic foci around cities located on endemic territories [1, 2]. Sverdlovsk, Chelyabinsk, Tyumen, and Kurgan regions are considered to be industrially developed with relatively high standards of living. These regions, excluding Kurgan region, are highly urbanized with specific weight of urban population in them being equal to $82,87,80$, and $62 \%$ respectively. Thus, population of Sverdlovsk region amounts to 4.4 million people and population density there is 22.6 people per 1 square kilometer. 3.5 million people live in Chelyabinsk region with population density there being 40.4 people per 1 square kilometer. Population of Tyumen region (without autonomous areas) is equal to 1.45 million people, and population density there is 8.2 people per 1 square kilometer; 0.85 million people live in Kurgan region with population density being 11.95 people per 1 square kilometer. All the above-mentioned regions are natural and anthropurgic foci of tick-borne infections [3-6].

Territories in Sverdlovsk, Chelyabinsk, and Kurgan regions are endemic in terms of TVE. As for Kurgan region, 19 out of 26 administrative territories there are endemic in terms of the disease [7]. Despite all specific and non-specific prevention activities performed by local public healthcare organizations and regional Rospotrebnadzor authorities, epidemic situation as per TVE remains rather complicated on endemic territories $[8,9]$.

Morbidity with TVE among population on endemic territories is known to depend directly on tick activity in spring and summer. There is a regular correlation between appliance for medical aid caused by a tick bite and morbidity [10]. People who haven't been vaccinated or whose vaccination hasn't been complete account for a considerable part of patients during annual peaks in morbidity with TVE in spring and summer. Rises and falls in morbidity on endemic territories are cyclic; this cyclicity is caused by biological factors (periodic changes in number of animals that are natural sources of nutrition for ticks) and weather and climatic factors (air temperature and humidity during a period when ticks are active) [11].

Growth in urban population resulted in significant increase in risk groups and, consequently, rise in morbidity with TVE. It called for changes in vaccination programs, namely, to switching from immunization that covered only occupational risk groups to mass vaccination of population in the Urals Federal District; as a result, over the last 10 years morbidity with TVE has decrease significantly, by 4 times in comparison with average long-term value, to be exact $[12,13]$.

From 1956 to 1999 there were rises and falls in morbidity that followed each other with an interval of 3-4 years. Since mass immunization against TVE was introduced in 1999, there has been a change in morbidity dynamics detected in the region $[12,14]$.

Our research goal was to describe dynamics in morbidity and number of people bitten by ticks in Chelyabinsk, Tyumen, Kurgan, and Sverdlovsk regions over 11 years (2007-2017) and draw up a short-time forecast for epidemic situation development based on mathematic modeling.

Data and methods. Long-term dynamics of morbidity with TVE in the Urals Federal District was examined on the basis of data taken from the Report Form No. 2 (state statistical reports) called "Data on infectious and parasitic diseases" provided by the Rospotrebnadzor Federal Center for Hygiene and Epidemiology. Data on people who were bitten by ticks in the Urals Federal District were taken from the annual State Reports on sanitaryepidemiologic welfare of the population issued by Rospotrebnadzor Regional Offices.

We found a logarithm of data on morbidity with TVE and number of people bitten by ticks to transform them into an additive scale and to stabilize the dispersion, We applied a sum of harmonic functions as a mathematical model:

$$
y=\Sigma\left[b_{i}+a_{i} \cos (\omega t+\varphi)\right],
$$

parameters of these functions (average value, amplitude, cyclic frequency, initial phase) were found with Levenberg - Marquardt non- 
linear procedure in "Statistica 12.0" applied software package (StatSoft). Flexibility of the procedure allows to both apply values of harmonic fluctuations parameters that are common for all regions and to assess contrasts existing between the regions that attracted our attention, for example, in average long-term values $\left(\Delta=b_{i}-b_{j}\right)$, in amplitudes $\left(\Delta=a_{i}-a_{j}\right)$, and other fluctuations parameters. The regions in the Urals Federal District were coded with slack variables - binary markers $(0$ or 1$)$; if a region was not included into a list of predictors, it set a reference (basic) level $\left(b_{0}\right)$, and contrasts for all the other regions were estimated against it. When regional markers are neglected, it creates a reduced model with overall estimation of parameters.

To compare and rank our models, we applied Akaike information criterion - AIC that determines optimality as a compromise between a model accuracy and complexity [15]. The lower $A I C$ value is, the more statistically relevant is a model. Models were compared on the basis of consistent Akaike information criterion calculated as per the following formula:

$$
C A I C=m \times \ln (R S S / m)+k \times[1+\ln (m)],
$$

where $m$ is a number of observations, RSS is a residual sum of squares or measure of variability not reproduced by a model, $k$ is a number of parameters. Therefore, the first summand in the formula measures accuracy of a model, and the second one, its complexity (number of parameters). This modification, in comparison with AIC, imposes stricter "penalties" for additional parameters [16-18].

"Weight" (relative plausibility) of each model calculated as per the following formula:

$$
w_{i}=\exp \left(-0,5 \times \Delta C A I C_{i}\right) / \Sigma \exp \left(-0,5 \times \Delta C A I C_{i}\right)
$$

was applied to rank and compare competing models. The obtained weights $\mathrm{w}_{\mathrm{i}}$ were interpreted as probabilities that $i$-th model was better than any other one from a variety of other pretender models. If weights were less than $10 \%$ different from $\mathrm{w}_{\max }$, models were considered to be of the same quality as the best one [15].
To assess dynamics in number of people bitten by ticks in the Urals Federal District regions over the observation period, and to predict how epidemiologic situation would develop in the next 5 years, we created several harmonic regression models with different number of estimated parameters.

A common logarithm of number of people bitten by ticks or average long-term morbidity for Kurgan region were taken as a reference (basic) level $\left(b_{0}\right)$ as the lowest number of people bitten by ticks was registered in this region out of all the considered ones, but the morbidity with TVE there was the highest.

We examined two interesting (working) models. The first one included binary ( 0 or 1$)$ predictors - markers for the regions in the Urals Federal District (Sverdlovsk, Chelyabinsk, and Tyumen region), for $b_{0}$ (basic level, Kurgan region), and fluctuations amplitudes. We applied amplitude value common for all the four regions in the second model. Cyclic frequency and initial phase were assumed to be common. The third model, or a "zero" one, included only an absolute term (average long-term morbidity common for all the regions). Model No. 2 was considered to be the most relevant to empirical data (Table 1), as the lowest CAIC value or the greatest "weight" ( $\mathrm{w}=0.989)$ was obtained for it. Therefore, given high statistical support, we can conclude that long-term fluctuations in number of people bitten by ticks change in common mode in the Urals Federal District.

A model for assessing morbidity with TVE consisted of two components. The first one reflected morbidity and changes occurring in it in the examined regions; the second one, in the RF in general.

We took each out of four regions as a reference level by turns and compared three models. We applied marker variables in the first model, both for average long-term morbidity and for fluctuations amplitude for regions in the Urals Federal District and the RF in general.

The second model included markers for the Urals Federal District regions, common assessment of amplitude for all four regions in the Urals Federal District and amplitude for morbidity in the RF in general; the third 
Models of harmonic fluctuations for showing dynamics in number of people bitten by ticks $\left(y=\log _{10}(N)\right)$ in 2007-2017 in the Urals Federal District regions

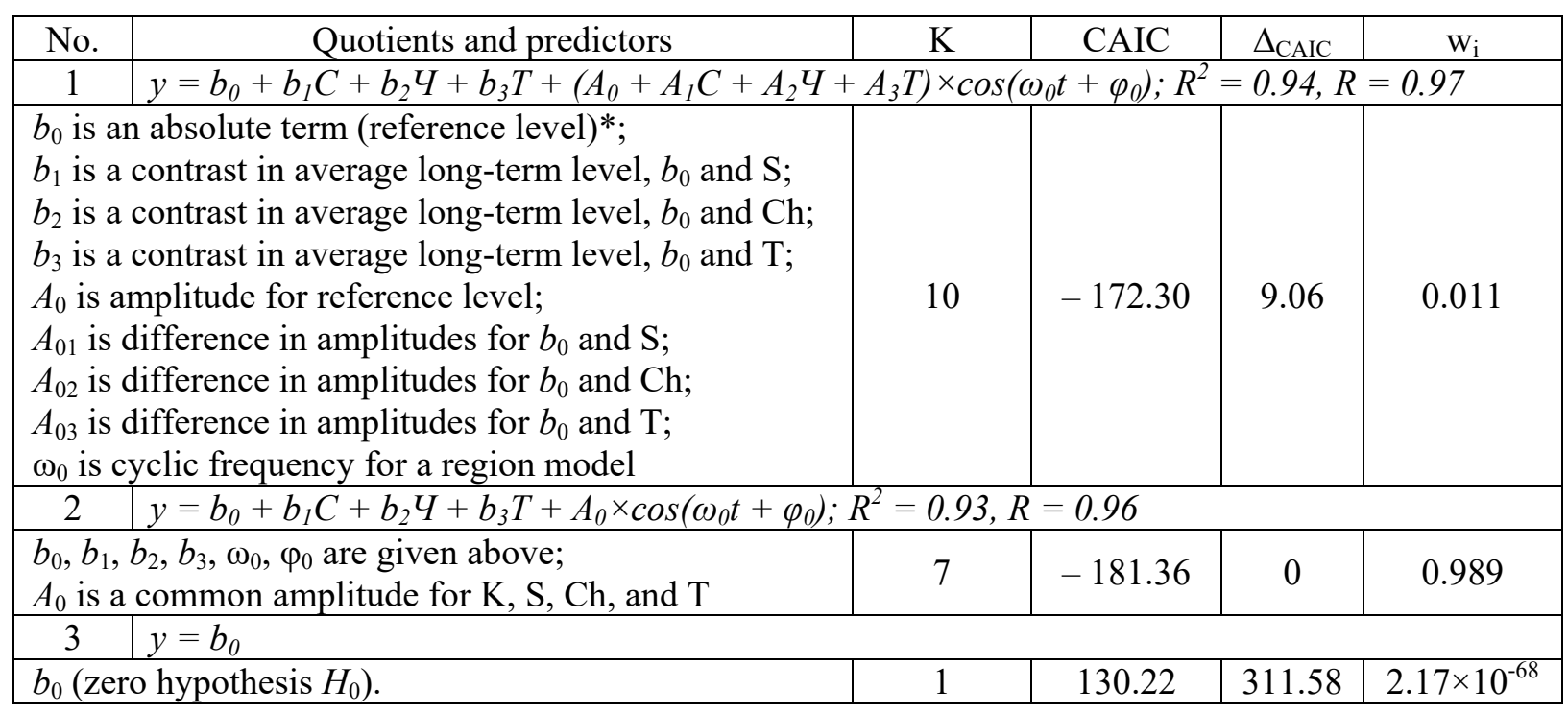

$\mathrm{N}$ o t e : CAIC is consistent Akaike information criterion; $\Delta_{\text {CAIC }}$ is differences in CAIC; $\mathrm{w}_{\mathrm{i}}$ is relative plausibility ("weight"); $\mathrm{k}$ is a number of parameters; * means that average value of the logarithm of number of people bitten by ticks in Kurgan region $(\mathrm{K})$ is taken in this model as reference level $\left(\mathrm{b}_{0}\right)$; $\mathrm{S}, \mathrm{Ch}$, and T are markers for Sverdlovsk, Chelyabinsk, and Tyumen region respectively.

model included an amplitude common for three regions (Sverdlovsk, Chelyabinsk, and Tyumen region), and specific amplitudes for Kurgan region and the RF in general. The fourth model that included only an absolute term was applied to compare predictions and to assess their quality.

This algorithm was also applied to assess morbidity with TVE in 2007-2017 (Table 2).

We chose Model No. 3 as a base for interpreting results of modeling morbidity with TVE as the lowest consistent Akaike criterion was obtained for it, and it also had the greatest "weight" among all the pretender models $(\mathrm{w}=0.96)$.

Results and discussion. Over 2007-2017 371,423 people were bitten by ticks in Sverdlovsk region, 1.743 TVE cases were registered, and average long-term morbidity amounted to 3.81 per 100 thousand people. 215,904 people were bitten in Chelyabinsk region, 1,078 TVE cases were registered $(2.98 \%$ \%000). 148,189 people were bitten in Tyumen region (data on the Khanty-Mansi Autonomous Area and YamalNenets Autonomous Area are not included in the figure) (5.92 per 100 thousand people).
Morbidity in Kurgan region where 54,906 people were bitten by ticks was the highest and amounted to $7.82 \%$. 0000 .

Determination quotient $\mathrm{R}^{2}$ (Table 1) amounted to $93 \%$ for a model that showed dynamics in a number of people bitten by ticks and it proves that this model chosen for interpretation is of high quality. The greatest number of people bitten by ticks over 11 years was registered in Sverdlovsk region, 34,674 people with hitting $95 \%$ interval from 30,200 to 39,811 . The lowest number of tick bites in 2007-2017 was registered in Kurgan region. As we ranked the examined regions in the Urals Federal District as per descending number of bitten people, we obtained the following sequence: Sverdlovsk region Chelyabinsk region - Tyumen region - Kurgan region (Table 3, Figure 1).

When creating a mathematical model for a number of people bitten by ticks, we detected cyclicity in the epidemic process with a quasi period equal to $8-8.5$ years (average $T=2 \pi / \omega=$ $=8.3$ years), with a confidence interval from 6.98 to 10.30 years. the created model allowed to detect a fluctuations amplitude $(p<0.0001)$. 
Таблица 2

Models of harmonic fluctuations for showing dynamics in morbidity (y) with TVE (per 100 thousand population) in 2007-2017 in the Urals Federal District regions

\begin{tabular}{|c|c|c|c|c|c|}
\hline № & Quotients and predictors & $\mathrm{k}$ & CAIC & $\Delta_{\text {CAIC }}$ & $\mathrm{W}_{\mathrm{i}}$ \\
\hline 1 & \multicolumn{5}{|c|}{$\begin{array}{l}y=b_{0}+\left\{x_{p} \times R F\right\}+\left(b_{1} S 1+b_{2} S 2+b_{3} S 3+\left(A_{0}+A_{01} S 1+A_{02} S 2+A_{03} S 3\right) \times\right. \\
\left.\times \cos \left(\omega_{0} t+\varphi_{0}\right)\right) \times\left[x_{p}=0\right]+\left(A_{1} \times \cos \left(\omega_{1} t+\varphi_{1}\right)\right) \times\left[x_{p}=1\right] ; R^{2}=0.78, R=0.88\end{array}$} \\
\hline \multicolumn{2}{|r|}{$\begin{array}{l}b_{0} \text { an absolute term (reference level); } \\
x_{p}-\text { контраст в СМУ PФ и } \mathrm{b}_{0} ; \\
b_{1} \text { is a contrast in average long-term morbidity, } b_{0} \text { and } \mathrm{S} 1 ; \\
b_{2} \text { is a contrast in average long-term morbidity, } \mathrm{b}_{0} \text { and } \mathrm{S} 2 ; \\
b_{3} \text { is a contrast in average long-term morbidity, } b_{0} \text { and } \mathrm{S} 3 ; \\
A_{0} \text { is amplitude for reference level; } \\
A_{01} \text { is difference in amplitudes for } b_{0} \text { and } \mathrm{S} 1 ; \\
A_{02} \text { is difference in amplitudes for } b_{0} \text { and } \mathrm{S} 2 ; \\
A_{03} \text { is difference in amplitudes for } b_{0} \text { and } \mathrm{S} 3 ; \\
\omega_{0} \text { is cyclic frequency for a region model (S); } \\
A_{1} \text { is an amplitude for the overall RF model; } \\
\omega_{1} \text { is cyclic frequency for the overall RF model. }\end{array}$} & 14 & 124.62 & 6.74 & 0.03 \\
\hline 2 & \multicolumn{5}{|c|}{$\begin{array}{l}y=b_{0}+\left\{x_{p} \times R F\right\}+\left(b_{1} S 1+b_{2} S 2+b_{3} S 3++A_{0} \times \cos \left(\omega_{0} t+\varphi_{0}\right)\right) \times\left[x_{p}=0\right]+ \\
+\left(A_{1} \times \cos \left(\omega_{1} t+\varphi_{1}\right)\right) \times\left[x_{p}=1\right] ; R^{2}=0.62, R=0.79\end{array}$} \\
\hline \multicolumn{2}{|r|}{$\begin{array}{l}b_{0}, x_{p}, b_{1}, b_{2}, b_{3}, \omega_{0}, \mathrm{~A}_{1}, \omega_{1} \text { are given above; } \\
A_{0} \text { ias a common amplitude for } b 0, \mathrm{~S} 1, \mathrm{~S} 2, \mathrm{~S} 3 .\end{array}$} & 11 & 139.97 & 22.00 & $1.62 \times 10^{-5}$ \\
\hline 3 & \multicolumn{5}{|c|}{$\begin{array}{l}y=b_{0}+\left\{x_{p} \times P \Phi\right\}+\left(b_{1} S 1+b_{2} S 2+b_{3} S 3+\left(A_{K O}+A_{C P} \times S_{C P}\right) \times \cos \left(\omega_{0} t+\varphi_{0}\right)\right) \times\left[x_{p}=0\right]+ \\
+\left(A_{1} \times \cos \left(\omega_{1} t+\varphi_{1}\right)\right) \times\left[x_{p}=1\right] ; R^{2}=0.77, R=0.88\end{array}$} \\
\hline \multicolumn{2}{|r|}{$\begin{array}{l}b_{0}, x_{p}, b_{1}, b_{2}, b_{3}, \omega_{0}, \mathrm{~A}_{1}, \omega_{1} \text { are givem above; } \\
A_{\mathrm{KR}} \text { is an amplitude for Kurgan region; } \\
A_{\mathrm{AV}} \text { is a difference between amplitudes for } \mathrm{S}_{\mathrm{KR}} \text { and } \mathrm{S}_{\mathrm{AV}} \\
\text { (average value as per } 3 \text { regions). }\end{array}$} & 12 & 117,88 & 0 & 0,96 \\
\hline 4 & $y=b_{0}$ & & & & \\
\hline \multicolumn{2}{|c|}{$b_{0}$ (zero hypothesis $H_{0}$ ). } & 1 & 195.94 & 78.06 & $1.08 \times 10^{-17}$ \\
\hline
\end{tabular}

$\mathrm{N}$ o t e : CAIC is consistent Akaike information criterion; $\Delta_{\text {CAIC }}$ is differences in CAIC; $\mathrm{w}_{\mathrm{i}}$ is relative plausibility ("weight"); $\mathrm{k}$ is a number of parameters; $\left\{\mathrm{x}_{\mathrm{p}} \times \mathrm{RF}\right\}$ is a summand in equations applied to take into account difference in average long-term levels between the RF and the examined regions; $\mathrm{x}_{\mathrm{p}}=0$ is a part of a model applied to show morbidity in the regions; $\mathrm{x}_{\mathrm{p}}=1$ is a part of a model applied to show morbidity in the RF; $b_{0}$ is an absolute term or a reference level which corresponds to average longterm morbidity in a chosen region; S1-3 are markers for the regions in the Urals Federal District.

Table 3

Parameters $(\theta)$, their standard errors (SE), and confidence intervals (CI) for the "best" model (from Table 1) for the logarithm of number of people bitten by ticks

\begin{tabular}{|l|c|c|c|c|c|c|c|c|}
\hline \multicolumn{1}{|c|}{ Parameters } & $\theta$ & $\mathrm{SE}(\theta)$ & $p$-value. & \multicolumn{2}{c|}{$95 \% \mathrm{CI}$} & \multicolumn{2}{c|}{$\theta \AA$} & \multicolumn{2}{c|}{$95 \% \mathrm{CI}$} \\
\hline $\begin{array}{l}\mathrm{b}_{0} \text { (average long-term level in } \\
\text { Kurgan region) }\end{array}$ & 3.69 & 0.03 & $<0.0001$ & 3.63 & 3.75 & 4,898 & 4,266 & 5,623 \\
\hline $\mathrm{b}_{1}$ (Sverdlovsk region) & 0.85 & 0.04 & $<0.0001$ & 0.75 & 0.93 & $34,674(+29,776)$ & 30,200 & 39,811 \\
\hline $\mathrm{b}_{2}$ (Chelyabinsk region) & 0.61 & 0.04 & $<0.0001$ & 0.53 & 0.70 & $19,953(+15,055)$ & 17,378 & 22,909 \\
\hline $\mathrm{b}_{3}$ (Tyumen region) & 0.45 & 0.04 & $<0.0001$ & 0.36 & 0.53 & $13,804(+8,906)$ & 12,023 & 15,488 \\
\hline $\begin{array}{l}\text { Common fluctuation amplitude } \\
\text { (S, Ch, T, and K) }\end{array}$ & 0.10 & 0.02 & $<0.0001$ & 0.06 & 0.15 & $\sim 26 \%$ & $\sim 15 \%$ & $\sim 41 \%$ \\
\hline $\begin{array}{l}\text { Cyclic frequency }\left(\omega_{0} \text { ) of fluc- }\right. \\
\text { tuations for a region model }\end{array}$ & -0.76 & 0.07 & $<0.0001$ & -0.90 & -0.61 & - & - & - \\
\hline
\end{tabular}

Note $: b_{0}$ is an absolute term (reference level) or an average value of the logarithm of a number of people bitten by ticks in Kurgan region; S, Ch, T, and K are markers for Sverdlovsk, Chelyabinsk, Tyumen, and Kurgan region respectively; $b_{1-3}$ are contrasts between each region in the Urals Federal District and Kurgan region; ${ }^{\circledR}$ means data are brought into an initial scale (number of people bitten by ticks) via potentiating logarithm values: $10^{(y)}=x$ - "anti-logarithm". 

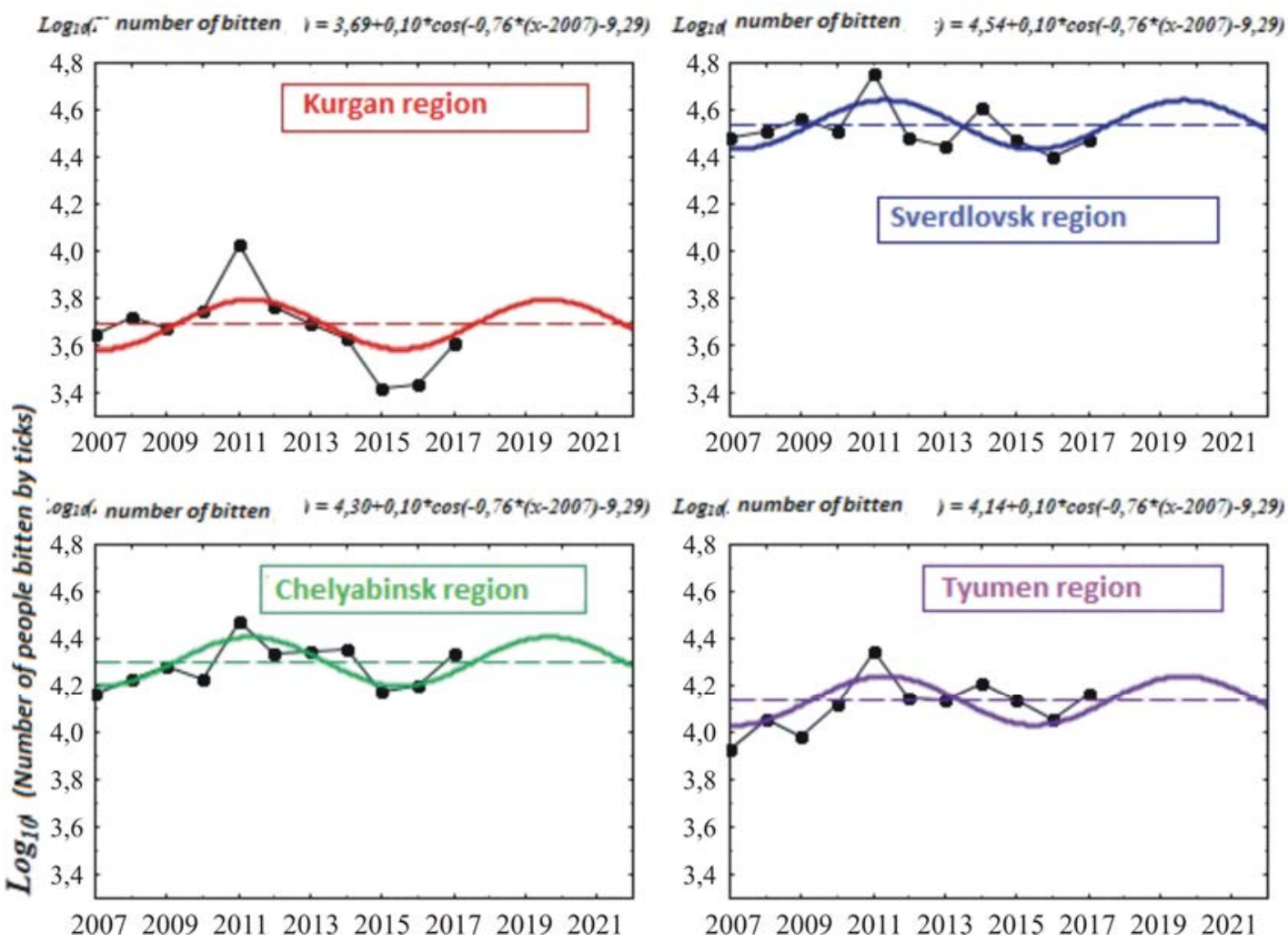

Figure 1. Dynamics in number of people bitten by ticks over 2007-2017 in four regions in the Urals Federal District and a forecast up to 2022

$\mathrm{N}$ o t e : dots on a polygonal line are observed values; broken straight lines show number of people bitten by ticks in the regions over 11 years; solid wavy lines represent values of logarithm of number of bitten people predicted by models for harmonic fluctuations

The greatest number of people bitten by ticks was detected in all four regions in the Urals Federal District in 2011. An increase amounted up to $26 \%$ from an average level calculated for 11 years with a confidence interval being equal to $15-41 \%$. Occurrence of a quasi period and amplitude allowed us to conclude that there was a cyclic dynamics in number of people bitten by ticks; this dynamics was most likely related to dynamics in populations of ticks and small mammals.

Substantial influence exerted by ecological and geographical factors on morbidity with TVE in the examined regions of the Urals Federal District was determined by value of the determination quotient $\mathrm{R}^{2}$ for this model; this value amounted to $77 \%$.

There are statistically significant discrepancies as per average long-term morbidity between four regions in the Urals Federal Dis- trict and average long-term morbidity in the RF in general (Table 4). Thus, average longterm morbidity in the examined regions (excluding Chelyabinsk region) differed significantly from average country level over 11 years. The greatest deviations from average long-term morbidity in the RF in general were detected in Kurgan and Tyumen region (the differences amounted to 6.03 and $4.13 \%$ 0000).

The highest average long-term morbidity was detected in Kurgan region where it was equal to 7.82 (CI: $6.63-9.01 \%$ \%000); this value was most probably caused by rises in the parameter that occurred in 2007-2012 with a local peak reached in 2011. the examined regions were ranked as per morbidity in descending order (Kurgan region - Tyumen region - Sverdlovsk region - Chelyabinsk region) and the results are shown in Table 5 and Figure 2. 
Table 4

Parameters $(\theta)$, their standard errors (SE), and confidence intervals (CI) for the best model (from Table 2) for harmonic fluctuations in morbidity with TVE

\begin{tabular}{|l|c|c|c|c|c|}
\hline \multicolumn{1}{|c|}{ Parameters } & $\theta$ & $\mathrm{SE}(\theta)$ & $p$-value & \multicolumn{2}{c|}{$95 \% \mathrm{CI}$} \\
\hline 1$) b_{0}$ (average long-term morbidity in Kurgan region) & 7.82 & 0.59 & $<0.0001$ & 6.63 & 9.01 \\
\hline$x_{p}(\mathrm{RF})$ & -6.03 & 0.99 & $<0.0001$ & -8.02 & -4.05 \\
\hline $\mathrm{b}_{1}$ (Sverdlovsk region) & -4.01 & 0.82 & $<0.0001$ & -5.67 & -2.36 \\
\hline $\mathrm{b}_{2}$ (Chelyabinsk region) & -4.84 & 0.82 & $<0.0001$ & -6.50 & -3.19 \\
\hline $\mathrm{b}_{3}$ (Tyumen region) & -1.90 & 0.82 & 0.03 & -3.56 & -0.25 \\
\hline Amplitude $(\mathrm{K})$ & 6.55 & 0.84 & $<0.0001$ & 4.85 & 8.25 \\
\hline Contrast in amplitudes [K]-[S, Ch, T] & -4.99 & 0.96 & $<0.0001$ & -6.93 & -3.05 \\
\hline 2) $b_{0}$ (average long-term morbidity in Sverdlovsk region) & 3.81 & 0.58 & $<0.0001$ & 2.64 & 4.97 \\
\hline$x_{p}(\mathrm{RF})$ & -2.02 & 0.98 & 0.05 & -3.99 & -0.04 \\
\hline $\mathrm{b}_{1}($ Chelyabinsk region) & -0.83 & 0.82 & 0.32 & -2.47 & 0.82 \\
\hline $\mathrm{b}_{2}$ (Tyumen region) & 2.11 & 0.82 & 0.01 & 0.47 & 3.76 \\
\hline $\mathrm{b}_{3}$ (Kurgan region) & 4.01 & 0.82 & $<0.0001$ & 2.36 & 5.67 \\
\hline 3$) b_{0}$ (average long-term morbidity in Chelyabinsk region) & 2.98 & 0.58 & $<0.0001$ & 1.81 & 4.14 \\
\hline$x_{p}(\mathrm{RF})$ & -1.19 & 0.97 & 0.23 & -3.16 & 0.77 \\
\hline $\mathrm{b}_{1}$ (Sverdlovsk region) & 0.83 & 0.82 & 0.32 & -0.82 & 2.47 \\
\hline $\mathrm{b}_{2}$ (Tyumen region) & 2.94 & 0.82 & 0.001 & 1.29 & 4.58 \\
\hline $\mathrm{b}_{3}$ (Kurgan region) & 4.84 & 0.82 & $<0.0001$ & 3.19 & 6.50 \\
\hline 4$) b_{0}$ (average long-term morbidity in Tyumen region) & 5.92 & 0.58 & $<0.0001$ & 4.75 & 7.08 \\
\hline$x_{p}$ (RF) & -4.13 & 0.98 & 0.0001 & -6.10 & -2.16 \\
\hline $\mathrm{b}_{1}$ (Sverdlovsk region) & -2.11 & 0.82 & 0.01 & -3.76 & -0.47 \\
\hline $\mathrm{b}_{2}$ (Chelyabinsk region) & -2.94 & 0.82 & 0.001 & -4.58 & -1.29 \\
\hline $\mathrm{b}_{3}$ (Kurgan region) & 1.90 & 0.82 & 0.03 & 0.25 & 3.56 \\
\hline Fluctuations amplitude common for S, Ch, and T & 1.57 & 0.48 & 0.002 & 0.60 & 2.53 \\
\hline Fluctuations amplitude for K & -4.99 & 0.96 & $<0.0001$ & -6.93 & -3.05 \\
\hline Cyclic frequency $\left(\omega_{0}\right.$ ) of fluctuations for region models & 0.59 & 0.04 & $<0.0001$ & 0.51 & 0.66 \\
\hline 5$)$ Fluctuations amplitude for the RF & 0.55 & 0.78 & 0.49 & -1.03 & 2.13 \\
\hline Cyclic frequency $\left(\omega_{1}\right.$ ) of fluctuations for the RF model & 0.44 & 0.75 & 0.56 & -1.08 & 1.96 \\
\hline
\end{tabular}

$\mathrm{N}$ o t e : $\mathrm{b}_{0}$ is an absolute term (reference level) showing average value of morbidity with TVE in a selected (reference) region; $\mathrm{S}, \mathrm{Ch}, \mathrm{T}$, and $\mathrm{K}$ are markers for Sverdlovsk, Chelyabinsk, Tyumen, and Kurgan regions respectively; $x p$ is a contrast between the RF and reference level; $b_{1-3}$ are contrasts between each region the Urals Federal District and reference level.

We should also note that we didn't detect any statistically significant discrepancies $(p=0.32)$ in average long-term morbidity between Sverdlovsk region and Chelyabinsk region; the issue most certainly requires further research.

Application of statistical models allowed to reveal cyclic changes (harmonic fluctuations) in morbidity with TVE in all the four regions in the Urals Federal District with a quasi period being equal to 10-11 years (average $T=2 \pi / \omega=10.6$ years) and a confidence interval from 9.52 to 12.31 .

It is well known that there are natural cyclic fluctuations in weather related to cyclicity observed in the solar activity as the great cycle of the Sun also lasts for 11 years [19]. As per data taken from literature, in previous years maximum in morbidity with TVE was observed in 1996 and 1999 in all the climatic zones in the Urals Federal District [19].

But at the same time, the highest average long-term morbidity and the greatest fluctuations amplitude was observed in Kurgan region (Figure 2). It can be due to a rise in morbidity in a period from 2007 to 2012 . The peak in morbidity was reached in Kurgan region, just as in three other regions, in 2010-2011. In those years morbidity was higher than its 

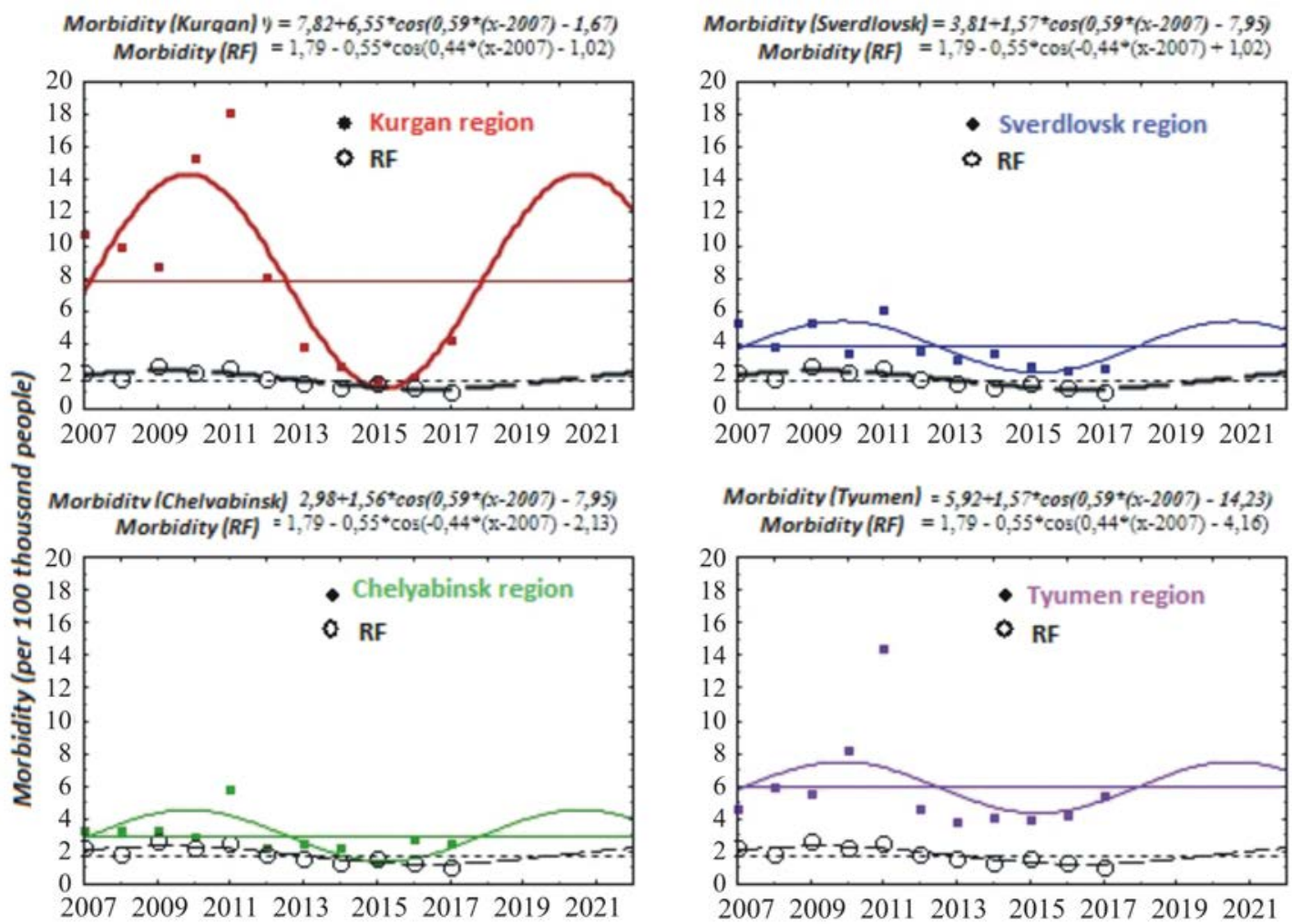

Figure 2. Dynamics in morbidity with TVE (per 100 thousand people) over 2007-2017 in four regions in the Urals Federal District and a forecast up to 2022

$\mathrm{N}$ o t e : dots (squares and rounds) are values being observed; solid straight lines show average long-term morbidity in the Urals Federal District regions; broken straight line shows average long-term morbidity in the RF in general; solid and broken curves show values predicted by models of harmonic fluctuations

average long-term level by $6.55 \%$ (CI: $4.85-8.25 ; p<0.0001)$. As per results obtained via statistical modeling, fluctuations amplitude observed in Sverdlovsk, Chelyabinsk, and Tyumen regions, was common for all three of them, and peak morbidity reached in this regions was higher than average long-term level by $1.57 \%$ (0000 (CI: $0.60-2.53 ; p=0.002$ ).

Conclusion. We analyzed morbidity with TVE over 2007-2017 years in Sverdlovsk, Chelyabinsk, Tyumen, and Kurgan regions; the analysis revealed statistically significant discrepancies between these regions in the Urals Federal District. The highest average long-term morbidity was registered in Kurgan region; the lowest, in Sverdlovsk and Chelyabinsk region. And at the same time, a number of people bitten by ticks over the same period was higher in Sverdlovsk, Chelyabinsk, and Tyumen region than in Kurgan region.
A smaller number of people bitten by ticks in Kurgan region against the other examined regions is most likely due to lower population in the region as there is always a direct correlation between population in a region and appliance for medical aid caused by tick bites. Extremely high morbidity with TVE in Kurgan region against all other regions is probably caused by both natural and social factors: there are several tick species that are infectious carriers (not only Ixodes, but also Dermacentor) and virus activity among them is also very high, specific and non-specific prevention activities performed in the region as regards TVE are not sufficient.

In our opinion, short-term forecasts for morbidity with TVE and appliance for medical aid caused by tick bites obtained on the basis of statistical models aren't indisputable as they are formed under influence exerted by many 
factors, and we require multi-factor analysis to take them all into account [20].

\section{Conclusions:}

1. We revealed statistically significant discrepancies between the four examined regions as per average long-term morbidity with TVE and number of people bitten by ticks. the highest average long-term morbidity was registered in Kurgan region (7.82 $\%$ 0000). Tyumen region followed (5.92), then Sverdlovsk region (3.81), and Chelyabinsk region (2.98). But as for number of people bitten by ticks, we observed a reverse descending sequence with maximum in Sverdlovsk region (34,674 people): Sverdlovsk region - Chelyabinsk region - Tyumen region - Kurgan region.

2. We made a forecast for morbidity with TVE and number of people bitten by ticks. In 2018-2022 we expect to see a rise in morbidity and number of people applying for medical aid due to tick bites in all the regions in the Urals Federal District. According to periodicity observed in the process (10-11 years), a peak in morbidity is most likely to occur in 2020-2021.

Funding. The research was not granted any sponsor support.

Conflict of interests. The authors state there is no any conflict of interests.

\section{References}

1. Ammosov A.D. Kleshchevoi entsefalit [Tick-borne encephalitis]. Kol'tsovo, Vektor-Best Publ., 2006, 115 p. (in Russian).

2. Korenberg E.I., Pomelova V.G., Osin N.S. Prirodnoochagovye infektsii, peredayushchiesya iksodovymi kleshchami [Infections with natural focality transmitted by ixodid ticks]. Moscow, Kommentarii Publ., 2013, 464 p. (in Russian).

3. Volkova L.I., Kovtun O.P., Tereschuk M.A. Klinicheskie osobennosti khronicheskogo kleshchevogo entsefalita i epilepsii Kozhevnikova na Srednem Urale [Clinical characteristics of chronical tickborne encephalitis and Kozhevnikov's epilepsia partialis continua in the Middle Urals]. Russkii zhurnal detskoi nevrologii, 2011, vol. 6, no. 2, pp. 3-10 (in Russian).

4. Zlobin V.I. Kleshchevoi entsefalit v Rossiiskoi Federatsii: etiologiya, epidemiologiya i strategiya profilaktiki [Tick-borne encephalitis in the Russian Federation: etiology, epidemiology and prevention strategy.]. Terra Medica, 2010, no. 2, pp. 13-21 (in Russian).

5. Luchinina S.V., Stepanova O.N., Pogodina V.V., Sten'ko E.A., Chirkova G.G. [et al.]. Sovremennaya epidemiologicheskaya situatsiya po kleshchevomu virusnomu entsefalitu v Chelyabinskoi oblasti [Modern Epidemiological Situation of Tick-Borne Encephalitis in Chelyabinsk Region, Russia]. Epidemiologiya i vaktsinoprofilaktika, 2014, vol. 75, no. 2, pp. 32-37 (in Russian).

6. Konkova-Reydman A.B., Ter-Bagdasaryan L.V. Sovremennye aspekty epidemiologii infektsii, peredayushchikhsya iksodovymi kleshchami [Modern aspects of epidemiology of ticks transmitted infections]. Epidemiologiya i infektsionnye bolezni, 2014, vol. 19, no. 5, pp. 26-31 (in Russian).

7. Yasyukevich V.V., Titkina S.N., Popov I.O., Davidovich E.A., Yasyukevich N.V. Klimatozavisimye zabolevaniya i chlenistonogie perenoschiki: vozmozhnoe vliyanie nablyudaemogo na territorii Rossii izmeneniya klimata [Climate-dependant diseases and arthropod vectors: possible influence of climate change observed in Russia]. Problemy ekologicheskogo monitoringa i modelirovaniya ekosistem, 2013, vol. 25, pp. 314-359 (in Russian).

8. Yastrebov V.K., Rudakov N.V., Shpynov S.N. Transmissivnye kleshchevye prirodno-ochagovye infektsii v Rossiiskoi Federatsii: tendentsii epidemicheskogo protsessa, aktual'nye voprosy profilaktiki [Transmissive tick-borne natural focal infections in the Russian Federation: trends of the epidemiological process, topical prophylaxis issues]. Sibirskii meditsinskii zhurnal, 2012, vol. 111, no. 4, pp. 91-93 (in Russian).

9. Il'in V.P., Andaev E.I., Balakhonov S.V., Pakskina N.D. Prognozirovanie zabolevaemosti kleshchevym virusnym entsefalitom v Rossiiskoi Federatsii v 2014 g., osnovannoe na mnogofaktornykh regressionnykh modelyakh [Morbidity Rate Forecasting for 2014 as Regards Tick-Borne Viral Encephalitis in the Territory of the Russian Federation Based on Multi-Factor Regression Models]. Problemy osobo opasnykh infektsii, 2014, no. 2, pp. 48-52 (in Russian). 
10. Noskov A.K., Il'in V.P., Andaev E.I., Pakskina N.D., Verigina E.V., Balakhonov S.V. Zabolevaemost' kleshchevym virusnym entsefalitom v Rossiiskoi Federatsii i po federal'nym okrugam $\mathrm{v}$ 2009-2013 gg., epidemiologicheskaya situatsiya v 2014 g. i prognoz na 2015 g. [Incidence of TickBorne Viral Encephalitis in the Russian Federation and across Federal Districts in 2009-2013. Epidemiological Situation in 2014 and Prognosis for 2015]. Problemy osobo opasnykh infektsii, 2015, no. 1, pp. 46-50 (in Russian).

11. Kiffner C., Zucchini W., Schomaker P., Vor T., Hagedorn P., Niedrig M., Rühe F. Determinants of tick-borne encephalitis in counties of southern Germany, 2001-2008. International Journal of Health Geographics, 2010, vol. 9, pp. 1-10. DOI: 10.1186/1476-072X-9-42

12. Heinz F.X., Stiasny K., Holzmann H. [et al.]. Vaccination and Tick-borne Encephalitis, Central Europe. Emerging Infectious Diseases, 2013, vol. 19, no. 1, pp. 69-76. DOI: 10.3201/eid1901.120458

13. Romanenko V.V., Kilyachina A.S., Yesyunina M.S., Ankudinova A.V., Pimenova T.A. Effektivnost' programmy massovoi immunoprofilaktiki kleshchevogo entsefalita [Efficiency of the program of mass immunoprophylaxis of Tick-Borne Encephalitis]. Biopreparaty. Profilaktika, diagnostika, lechenie, 2008, no. 2, pp. 9-14 (in Russian).

14. Yesyunina M.S., Romanenko V.V., Kilyachina A.S. Dlitel'nost' sokhraneniya postprivivochnogo immuniteta $\mathrm{k}$ virusu kleshchevogo entsefalita posle revaktsinatsii [Duration of post-vaccination immunity against tick-borne encephalitis following booster doses]. Trudy Instituta poliomielita $i$ virusnykh entsefalitov imeni M.P. Chumakova RAMN. Meditsinskaya virusologiya, 2015, vol. 29, no. 2, p. 132 (in Russian).

15. Akaike H. A new look at the statistical model identification. IEEE Transactions on Automatic Control, 1974, vol. 19, pp. 716-723.

16. Anderson, D.R., Burnham, K.P., White, G.C. Comparison of Akaike information criterion and consistent Akaike information criterion for model selection and statistical inference from capturerecapture studies. Journal of Applied Statistics, 1998, vol. 25, pp. 263-282.

17. Burnham K.P., Anderson D.R. Model selection and multimodel inference: a practical information-theoretic approach. New York, Springer Verlag Publ., 2002, 496 p.

18. Yang Y. Can the strengths of AIC and BIC be shared? A conflict between model indentification and regression estimation. Biometrika, 2005, vol. 92, no. 4, pp. 937-950.

19. Tsokova T.N., Kozlov L.B. Razrabotka matematicheskoi modeli prognozirovaniya zabolevaemosti kleshchevym entsefalitom [Development of mathematical model of forecasting of desease the virus of tick-born encephalitis]. Uspekhi sovremennogo estestvoznaniya, 2008, no. 6, pp. 12-16 (in Russian).

20. Stefanoff P., Rubikowska B., Bratkowski J., Ustrnul Z., Vanwambeke S.O., Rosinska M. A Predictive Model Has Identified Tick-Borne Encephalitis High-Risk Areas in Regions Where No Cases Were Reported Previously, Poland, 1999-2012. International Journal of Environmental Research and Public Health, 2018, vol. 15, no. 4, pp. 1-17. DOI: 10.3390/ijerph15040677

Mishchenko V.A., Ladygin O.V., Bykov I.P., Zakharova J.A., Sergeev A.G., Kshnyasev I.A. Morbidity with tick-borne viral encephalitis in some regions in uralskiy federal district with predictive estimate of short-term epidemiologic situation. Health Risk Analysis, 2019, no. 1, pp. 68-77. DOI: 10.21668/health.risk/2019.1.07.eng

Received: 06.11.2018

Accepted: 02.03.2019

Published: 30.03.2019 